\title{
Mutacja BRCA1 4153delA („,bałtycko-czarnomorska”) u chorych na raka piersi na Ukrainie
}

\author{
Nataliya Kitsera ${ }^{1}$, Yaroslav Shparyk², Borys Bilynsky³, \\ Ivanna Duda², Taras Kachmar², Olha Oleksyak²
}

Rak piersi (RP) jest najczęstszą postacią raka występującą w populacji kobiet na Ukrainie.

Cel. Analiza najczęstszych mutacji w genach BRCA1/2 u kobiet na Ukrainie Zachodniej chorych na raka piersi (RP), obciążonych genetycznie tą patologią.

Materiał i metody. Kliniczne i genealogiczne badanie objęło 335 pacjentek chorych na RP konsultowanych w Oddziale Chemioterapii (Lwowskiego Państwowego Regionalnego Centrum Onkologicznego Leczniczo-Diagnostycznego) w okresie luty-wrzesień 2012 r. w celu stwierdzenia występowania nowotworów złośliwych u krewnych. Poprzez metody molekularno-genetyczne określono obecność siedmiu mutacji w genie BRCA1 (185delAG, 4153delA, 5382insC, 188del11, 5396 +1 G> A, 185InsA, 5331 G> A) i 3 mutacje w genie BRCA2 (6174delT, 6293S> G, 6024delTA), odpowiedzialnych za dziedziczne formy RP.

Wyniki. Kliniczno-genealogiczne badanie 335 pacjentek chorych na RP wykazało, że u co dziewiątej z nich (u 36, czyli u 10,7\%) były stwierdzone przypadki RP wśród krewnych.

W grupie 125 kobiet ze stwierdzonym rodzinnym obciążeniem RP w 5 przypadkach (4\%) zidentyfikowano mutacje w genach BRCA1/2 (5382insC - 2, 185delAG - 2 i 4153delA - 1). Wszystkie zidentyfikowane mutacje stanowiły trzy najczęściej spotykane przypadki opisane w literaturze w Europie Środkowej i Wschodniej (geograficznie — regionie Morza Bałtyckiego i Czarnego).

Wniosek. Wśród wszystkich zidentyfikowanych mutacji (BRCA1 185delAG, 5382insC i 4153delA) u kobiet chorych na RP na Ukrainie Zachodniej stwierdzono trzy najczęściej cytowane mutacje w literaturze Europy Środkowej i Wschodniej oraz siedem mutacji rzadszych.

\section{BRCA1 4153delA mutation ("Baltic/Black Sea") in breast cancer patients in Ukraine}

Purpose. To analyze the most common mutations in the genes BRCA1/2 among women from West Ukraine with breast cancer $(B C)$ who are burdened with a family history of this pathology.

Materials and methods. 335 patients with $(B C)$ from West Ukraine studied pedigrees and 125 DNA samples. A molecular-genetic method determined the presence of seven mutations in the gene BRCA1 (185delAG, 4153delA, 5382InsC, 188del11, $5396+1$ G> A, 185InsA, 5331 G> A) and 3 gene mutations in BRCA2 (6174delT, 6293S> G, 6024delTA).

Results. Only every 9th patient with $B C$ had $B C$ in his family history. It is this group we examined in detail for the $B R C A 1 / 2$ gene mutations presence.

$B R C A 1 / 2$ gene mutations were found in 5 patients (4\%) among 125 women with $B C$ who are burdened with family history of this pathology. In 2 cases diagnosed mutation of the gene BRCA1 (5382 Ins C), and 2 - BRCA1 185 del AG, $4153 \mathrm{del} A-1$. All mutations belonged to the group of founder mutations in the ethnic group of Ashkenazi Jews and the geographical group of Baltic-Black Sea region.

\footnotetext{
${ }^{1}$ Instytut Patologii Dziedziczenia

Narodowa Akademia Nauk Medycznych we Lwowie, Ukraina

${ }^{2}$ Lwowskie Regionalne Leczniczo-Diagnostyczne Centrum Onkologii we Lwowie, Ukraina

${ }^{3}$ Lwowski Narodowy Uniwersytet Medyczny im. Daniela Halickiego we Lwowie, Ukraina
} 
This is the first reported detection of BRCA1 4153delA mutations in woman with $B C$ in Ukraine. We described BC caused by gene BRCA1 4153delA mutation, in a 73-years woman, who had only one grandmother in mother's line with $B C$ in her family tree. She has two daughters (one had a childless marriage, the second's daughter child died at the age of 1 day, and the next pregnancy ended in miscarriage in the early stages). The patient had BRCA1 4153delA mutation typical gene mutation caused by $B C$ receptor status - estrogen and progesterone resistant. Family history of reproductive anamnesis in patient's daughters can be attributed with ovarian failure, which is associated with mutation of the gene BRCA1 4153delA mutation by some researchers.

Conclusion All identified mutations (BRCA1 185delAG, 5382insC and 4153delA) among women with BC from West Ukraine. These are the three most common according to the literature in Eastern and Central Europe, while less common seven mutations were found.

Słowa kluczowe: rak piersi, mutacje $B R C A 1 / 2, B R C A 14153$ delA, kobiety, drzewo genealogiczne, Ukraina Key words: breast cancer, mutation BRCA1/2, BRCA1 4153delA, women, family tree, Ukraine

NOWOTWORY Journal of Oncology 2014; 64, 3: 246-250

\section{Wstęp}

Rak piersi (RP) jest najczęstszym nowotworem złośliwym u kobiet na Ukrainie; w latach 2010 i 2011 stwierdzono, odpowiednio, 17410 i 16325 nowych zachorowań [1]. Zachorowalność w 2010 roku wyniosła 23,9 (częstość standaryzowana do wieku, age-standardised) na 100000 osób, a śmiertelność we Lwowie, Ukraina 10,1 na 100 000. Przewidywana śmiertelność z powodu RP w krajach Unii Europejskiej w 2013 r. wynosi 14,6 na 100000 [2].

Walka z chorobą nie może być skuteczna bez znajomości jej etiologii. Wiadomo, że występowanie RP w około 7-10\% spowodowany jest przez czynniki dziedziczne i genetyczne. Najlepiej zbadane są mutacje w genach BRCA1/2, które znane są w ilości większej niż dwa tysiące i wciąż odkrywane [3].

$Z$ drugiej strony, epidemiologiczne badania genetyczne u pacjentek o różnym pochodzeniu etnicznym wykazują, że w jednorodnych grupach etnicznych dominuje występowanie mutacji wspólnych, które czynią z nich bezwzględną większość.

Przedstawiamy wyniki naszych badań przeprowadzonych w Regionalnym Leczniczo-Diagnostycznym Centrum Onkologii we Lwowie.

\section{Materiał i metody}

W okresie luty-wrzesień 2012 roku przeprowadzono kliniczno-genealogiczne badanie 335 pacjentów (w tym 2 mężczyzn) chorych na RP („,bieżąca niewyselekcjonowana grupa pacjentów") konsultowanych w Oddziale Chemioterapii Lwowskiego Państwowego Regionalnego Leczniczo-Diagnostycznego Centrum Onkologicznego, w celu stwierdzenia występowania nowotworów złośliwych u krewnych.

Do tej pory na Ukrainie tylko pojedyncze grupy badaczy oceniały mutacje w genach $B R C A 1 / 2$, ale w przeciwieństwie do naszego badania mutacje oznaczone były metodą immunohistochemiczną bez identyfikacji lokusu, a w innych przypadkach diagnozowano nie więcej niż 3-5 mutacji.
Metodami molekularno-genetycznymi u 125 pacjentów (laboratorium „EuroLab”, Kijów, Ukraina) określono obecność siedmiu mutacji w genie BRCA1 (185delAG, 4153delA, 5382insC, 188del11, $5396+1$ G> A, 185InsA, 5331 G> A) i trzech mutacji w genie BRCA2 (6174delT, 6293S> G, 6024delTA) odpowiedzialnych za dziedzicznego RP. DNA ekstrahuje się z limfocytów krwi obwodowej za pomocą standardowej ekstrakcji fenolem-chloroformem. Nomenklaturę mutacji ustalono według bazy danych BIC (Breast Cancer Information Core). Określenie mutacji allelu badano za pomocą specyficznej reakcji łańcuchowej polimerazy (PCR) oraz analizy długości fragmentów restrykcyjnych (RFLP).

\section{Wyniki}

Aby ustalić występowanie nowotworów złośliwych u krewnych chorych na RP, oceniono drzewa genealogiczne 335 pacjentów. W drzewach genealogicznych 175 (52,2\%) pacjentów chorych na RP nie obserwowano nowotworów złośliwych wśród krewnych.

U nieco mniej niż połowy (160, tj. 47,8\%) odnotowano przypadki choroby nowotworowej u krewnych. U 123 (36,7\%) chorych rozpoznano przypadki choroby nowotworowej u krewnych — po jednym przypadku w 100 rodzinach (w tym 19 rodzin z notowanymi przypadkami zachorowań na RP). Wśród 23 pacjentów było dwa lub więcej przypadków raka u krewnych, w tym u 16 - RP. U 37 (11\%) pacjentów były 3 lub więcej chorych na raka wśród krewnych, gdzie 16 osób miało RP.

W odniesieniu do RP - w rodzinach 36 spośród 335 (10,7\%) pacjentów obserwowano 51 przypadków RP (w 28 - po jednym, u 10 - po dwa, zaś u jednej pacjentki — w trzech przypadkach — za wyjątkiem jej samej). Wśród krewnych pacjentów były: matki (u 9 chorych), siostry (9) i córki (3), babki (6, w tym u 5 - po linii matki), ciotki (17, w tym u 13 - po linii matki), dalecy krewni (7). 
Tak więc u każdej co dziewiątej pacjentki obserwowano RP w rodzinie. Tę grupę zbadano szczegółowo na obecność mutacji w genach BRCA1/2. W latach 2008-2013 wśród 125 kobiet z rodzinnym RP w 5 (4\%) przypadkach zidentyfikowano mutacje $w$ genach $B R C A 1 / 2$. Zdiagnozowano mutacje BRCA1 5382insC (2 pacjentki) i BRCA1 185delAG (2 pacjentki), a w jednym przypadku - BRCA1 4153delA. Jest to pierwsza na Ukrainie potwierdzona informacja o wykryciu mutacji BRCA1 4153delA u kobiety chorej na RP. Opisany przypadek RP spowodowany mutacją genu BRCA 14153 delA wystąpił u 73-letniej kobiety, która miała tylko jedną babcię po linii matki chorą na RP w swoim drzewie genealogicznym. Pacjentka ma dwie córki (u jednej — małżeństwo bezdzietne, u drugiej dziecko zmarło w pierwszym dniu po porodzie, a następna ciąża zakończyła się wczesnym poronieniem). Stan receptorów u wspomnianej pacjentki był typowy dla mutacji genu BRCA1 - estrogen/progesteron był ujemny. Rodzinna historia rozrodu córek pacjentki może być wyjaśniona niewydolnością jajników, którą niektórzy badacze łączą z mutacją genu BRCA1. Cechami opisanego przypadku RP, spowodowanego mutacją genu BRCA1 4153delA, jest stosunkowo podeszły wiek pacjentki i nieznaczna akumulacja rodzinna tej patologii.

Wszystkie zidentyfikowane mutacje: trzy najczęściej spotykane - zgodnie z literaturą - mutacje w Europie Środkowej i Wschodniej, natomiast innych siedem mutacji nie znaleziono. U 4 z 5 chorych stan receptorów guza był nieczuły na terapię hormonalną, tj. ER(-), PR(-).

\section{Dyskusja}

Uważa się, że częstość występowania mutacji genu BRCA charakteryzuje się wyraźnym efektem założyciela (founder effect) - dominują tu powtarzające się mutacje w genach BRCA1 i BRCA2 (zwłaszcza u Żydów aszkenazyjskich prawie wszystkie geny $B R C A 1$ i $B R C A 2$ są uszkodzone mutacją BRCA1 185delAG, BRCA1 5382insC lub BRCA2 6174delT) [4]. Gdy część populacji przemieszcza się do nowych obszarów, pula genów migrantów staje się niewielką częścią oryginalnej puli genowej populacji miejscowej. Dlatego też do nowego obszaru dociera tylko część wariantów genetycznych (alleli) znajdujących się w zakresach źródłowych. Potomkowie imigrantów mnożąc się mogą nawet z czasem liczbowo przewyższyć liczebność ludności „miejscowej”, ale ich różnorodność genetyczna pozostanie nieznaczna, a częstość alleli będzie się różnić od ich przodków. Zjawisko to nazywane jest „efektem założyciela". Jego wynikiem jest naturalne zmniejszenie się różnorodności genetycznej osób w miarę powiększania się odległości od pierwotnego osiedlenia. Im mniej liczne są grupy migrantów zasiedlających nowe terytorium, tym silniejszy jest „efekt założyciela”.

„Efekt założyciela” w raku piersi znaleziono w etnicznej grupie Żydów aszkenazyjskich. Pierwsze badanie przepro- wadzono w USA [4], a później wśród Żydów aszkenazyjskich w Izraelu [5], Australii [6], w Ameryce Południowej [7] i w niektórych krajach europejskich [8].

Mutacje założycielskie wynoszą nawet $85-90 \%$ wszystkich mutacji dziedzicznych (RP) i raka jajników (RJ) [4]. Dotychczas opublikowano wyniki kilkunastu badań nad występowaniem mutacji $B R C A$ w różnych krajach i grupach etnicznych. W ostatniej metaanalizie w 29 takich badaniach znaleziono 20 mutacji „założyciela”'. Najczęstsze z nich to 4 mutacje BRCA 1 (5382insC, 185delAG, 3819del5 i 4153delA) i 2 mutacje BRCA2 (4075delGT, 5802del4). Wśród mutacji BRCA1 5382insC ogólna częstotliwość wynosiła 0,09, 185delAG - 0,07, 4153delA - 0,06, 3819del5 - 0,02 [9].

Sugeruje to logicznie, że inne grupy etniczne mogą różnić się w spektrum mutacji założyciela od Żydów aszkenazyjskich. Nas interesują mutacje, które występują najczęściej w Europie Środkowej i Wschodniej. Już w pierwszym artykule, gdzie badano występowanie mutacji BRCA u kobiet w Rosji stwierdzono, że wśród 19 pacjentek z rodzinnym RJ u 9 znaleziono mutację 5382insC (w tym 2 u Żydówek aszkenazyjskich) i u 3 - mutację 4153delA (wszystkie pacjentki były Rosjankami z Moskwy) [10]. Biorąc pod uwagę dużą geograficzną przestrzeń i różnorodny skład etniczny ludności, nie jest zaskakujące, że częstość występowania różnych mutacji różni się między sobą. W szczególności mutacja 4153delA, która — stwierdzona u dwóch pacjentek z RJ w Petersburgu - była nieobecna u pacjentek z Krasnodaru. Z drugiej strony - w obu obszarach dominuje mutacja 5382insC [11].

W Petersburgu w grupie 302 chorych z RP, które miały objawy kliniczne (dwustronność dziedziczności i/lub wiek początku RP < 40 lat), zidentyfikowano 8 różnych mutacji u 46 pacjentów. Najczęstszymi były również 5382insC — u 29 (9,6\%) pacjentek i 4153delA — u 3 (1,0\%). Uważa się, że mutacje BRCA1 założyciela (5382insC, 4153delA, 185deIAG) są w Rosji odpowiedzialne za około 15\% RP z klinicznymi objawami dziedziczności [12]. W Nowosybirsku mutacji 4153delA nie znaleziono wśród 7920 osób zdrowych i tylko w jednym przypadku była diagnozowana u 570 pacjentów z RP $(0,18 \%)$ [13].

Liczne badania na temat grupy mutacji genów $B R C A$ prowadzono przez polskich onkologów. Wśród 200 rodzin z silnym elementem dziedzicznym RP i/lub RJ mutacje BRCA1 znaleziono w 122 rodzinach (61\%), zaś mutacje $B R C A 2$ - u 7 rodzin (3,5\%), a 119 spośród 122 mutacji BRCA1 (97,5\%) powtarzało się. Zdecydowaną większość (111 rodzin, tj. 86\%) stanowiły trzy mutacje założyciela (5382insC, C61G, 4153delA) [4]. Wyniki te zostały potwierdzone przez Górskiego i wsp. W 35 przypadkach z 66 badanych rodzin z dziedzicznym $\mathrm{RP}$ i/lub $\mathrm{RJ}$ z różnych regionów Polski znaleziono mutację $B R C A$, w tym - mutacje założyciela 5382insC, C61G i 4153delA (51\%, 20\% oraz $11 \%$ ze wszystkich zidentyfikowanych mutacji) [14]. 
Wśród 2012 niewyselekcjonowanych chorych na RP z 9 polskich miast znaleziono 2,9\% przypadków wspomnianych wyżej trzech mutacji założyciela [15]. Podobne wyniki uzyskał Gronwald J i wsp. [16]. Testowano 3568 chorych na RP diagnozowanych w młodym wieku oraz 609 chorych na RJ. Mutacje założyciela stwierdzono u 273 (187 - 5382insC, 22 - i64 4153delA - C61G). Wspomniane mutacje wystąpiły u 4,3\% pacjentek z RP oraz u 12,3\% pacjentek z RJ. Ze względu na rozpowszechnienie tych trzech mutacji polecano przeprowadzenie skriningu (przesiewu) genetycznego RP i RJ w Polsce głównie wśród nich [17]. Mutacja 4153delA jest spotykana w różnych województwach Polski, w szczególności w Małopolsce [18] oraz na Mazowszu [19], natomiast na Górnym Śląsku bezwzględna większość mutacji (11 z 15 mutacji w 148 rodzinach z rodzinnym RP/RJ) była mutacją 5382insC. Mutacja 4153delA nie była stwierdzona [20]. W analizie 63 rodzin z RP i/lub RJ z Pomorza i Kujaw jedną z trzech mutacij założyciela zidentyfikowano w 9 rodzinach (sześć - 5382insC i trzy - 300T> G) [21]. Należy zauważyć, że większość z tych regionów Polski zachodniej, w których mutacji 4153delA nie znaleziono, nie wchodziła w skład ziem dawnej Rzeczypospolitej.

W Izraelu mutację 4153delA stwierdzono u 2 pacjentek z 285 rodzin wysokiego ryzyka genetycznego RP i/lub RJ; pochodziły one z Polski i byłego Związku Radzieckiego. Nie była to mutacja znaleziona u Żydów aszkenazyjskich $(n=500)$ [22].

Na Białorusi mutacja 4153delA jest jedną z trzech najczęstszych i ma więcej związków z rozwojem RJ niż RP [23]. Sylyn i wsp. przeprowadzili analizę genetyczną 667 próbek DNA 8 najczęstszych w Europie Wschodniej mutacji genów BRCA1 i BRCA2 od pacjentów chorych na RP bez występowania czynników dziedzicznych [11].Znaleziono 75 mutacji, wśród których w 60 przypadkach (tj. 80\% wszystkich diagnozowanych mutacji) była to mutacja 5382insC. Oprócz tego rozpoznano pięć mutacji 185delAG oraz - po cztery -4153delA i 300T> G, a w dwóch przypadkach - 6174delT. Trzy inne mutacje nie ujawniły się w żadnym przypadku. W Estonii w grupie 144 chorych na RP i osób zdrowych (64 pacjentki chore na RP w wieku do 45 lat, 47 pacjentek z RP rodzinnym i 33 zdrowych osób z rodzin obciążonych RP i/lub RJ) znaleziono siedem przypadków mutacji 5382insC, trzy - 4153delA oraz jeden - c.3881 - 3882delGA [24].

Na Litwie najbardziej powszechne są trzy takie same mutacje założycielskie RP i RJ jak w Polsce i na Białorusi [25]. Jedną z trzech mutacji założyciela na Litwie znaleziono u 9 z 13 rodzin, w których były co najmniej trzy przypadki RP i/lub RJ, w tym większość (5 przypadków) — to mutacja 4153delA [26].

Na Łotwie dwie mutacje (5382insC i 4153delA) stanowią $80 \%$ wszystkich mutacji BRCA [27]. Mutacje założyciela genu BRCA1 stwierdzono w 9 przypadkach wśród 287 chorych na RP i/lub RJ, przy tym dwie wymienione mutacje wystąpiły cztery razy [28]. Według innych badań w tym kraju mutacja 5382insC oraz C61G wynosi 63\% (5 z 8) i 25\% (2 z 8), a 4153 delA - tylko 12\% (1 z 8) [29].

Ozolina i wsp., analizując mutację 4153delA w trzech państwach (Rosja, Łotwa, Polska), sugerują, że ma ona wspólne pochodzenie [30]. W naszej opinii mutacja 4153delA ma nie tak etniczną, jak geograficzną wspólność - i poszerzona w ziemiach między Bałtykiem a Morzem Czarnym odpowiada terytorium Wielkiego Księstwa Litewskiego, które istniało już w XIII-XVIII wieku, a później — Rzeczypospolitej. Region ten ma wiele historycznych podobieństw, co logicznie może stworzyć warunki do genetycznego pokrewieństwa. Nie jest więc zaskakujące, że nawet współcześni politycy doceniają wspólną perspektywę tego regionu Europy [31].

Obecność mutacji 4153delA ma różne znaczenia dla różnych rodzajów raka. Według polskich badaczy mutacje 5382insC i 4153delA zwiększą ryzyko RJ 43-50 razy, natomiast obecność mutacji 4153delA w RP jest znacznie mniej istotna, niż obecność innych mutacji założyciela [15]. Analiza chorych na RJ z Rosji wykazała, że mutacja 4153delA wystąpiła tylko u 2 ze 177 pacjentek i jej znaczenie dla rozwoju RJ jest kwestionowane [32].

Mutacji 4153delA nie wykryto u żadnego z 88 pacjentów chorych na raka trzustki w Polsce [33] oraz u żadnego ze 196 pacjentów chorych na raka gruczołu krokowego na Łotwie (natomiast u 2112 pacjentów stwierdzono mutację 5382insC) [34]. W analizie chorych na raka prostaty w Polsce uzyskano inne wyniki. Mutacje znaleziono w jednym przypadku na $1793(0,06 \%)$, podczas gdy w grupie kontrolnej stwierdzono je w 0,37\% przypadków ( $n=4570)$. W przeciwieństwie do tego mutacja 4153delA występowała częściej u pacjentów chorych na raka gruczołu krokowego niż w grupie kontrolnej (0,22\% w stosunku do 0,04\%) [35]. Ponadto ta mutacja związana jest z rozwojem raka prostaty w młodym wieku [36].

\section{Wnioski}

1. W bieżącej niewyselekcjonowanej grupie chorych na RP u co dziewiątej pacjentki (36 z 335, czyli 10,7\%) notowano przypadki RP wśród krewnych.

2. W grupie 125 kobiet $z$ rodzinnym RP w 5 (4\%) przypadkach zidentyfikowano mutacje $w$ genach BRCA1/2 (5382insC - 2, 185delAG - 2 i 4153delA - 1). Wszystkie to trzy najczęściej spotykane, zgodnie z literaturą, mutacje w Europie Środkowej i Wschodniej.

3. Do tej pory badania na wykrywanie szerokiego spektrum mutacji w genach $B R C A 1 / 2$ na Ukrainie nie były prowadzone. Mutację BRCA1 4153delA u pacjentki chorej na RP na Ukrainie diagnozowano po raz pierwszy.

4. Mutację 4153 delA wykryto u pacjentów z RP i/lub RJ na Łotwie, Litwie, w Estonii, w Polsce (z wyjątkiem zachodniego regionu), Białorusi i Rosji (zwłaszcza w Moskwie 
i Petersburgu, ale nie na Kubaniu na Syberii), jak również u nie-Żydów — w Izraelu — u imigrantów z tych krajów.

5. Diagnozowanie tej mutacji na Ukrainie sugeruje, że nie jest ona etniczną, i może być nazwana „bałtycko-czarnomorską".

\section{Podziękowanie}

Wyrażamy naszq wdzięczność Aleksiejowi Kashynu iAntoninie Sholokh z Laboratorium "EuroLab" w Kijowie za pomoc podczas oznaczania dziesięciu mutacji w genach BRCA1/2.

\section{Dr n. med. Nataliya Kitsera}

Instytut Patologii Dziedziczenia

Narodowa Akademia Nauk Medycznych we Lwowie, Ukraina

e-mail:nkitsera@gmail.com

\section{Otrzymano: 28 października 2013 r.}

Przyjęto do druku: 8 kwietnia 2014 r.

\section{Piśmiennictwo}

1. Fedorenko ZP, Goulak LO, Gorokh YL i wsp. Cancer in Ukraine, 2010-2011. Incidence, mortality, activities of oncological service. Bulletin of National Cancer Registry of Ukraine. Kyiv, 2012. http://www.ucr.gs.com. ua/dovidb0/index_e.htm

2. Malvezzi M, Bertuccio $P$, Levi Fi wsp. European cancer mortality predictions for the year 2013. Ann Oncol 2013; 24: 792-800.

3. http://www.myriad.com/.

4. Ganguly A, Leahy K, Marshall AM i wsp. Genetic testing for breast cancer susceptibility: frequency of BRCA1 and BRCA2 mutations. Genet Test 1997; 1: 85-90.

5. Modan B, Gak E, Sade-Bruchim RB i wsp. High frequency of BRCA 185delAG mutation in ovarian cancer in Israel. National Israel Study of Ovarian Cancer. JAMA 1996; 276: 1823-1825.

6. Bahar AY, Taylor PJ, Andrews L i wsp. The frequency of founder mutations in the BRCA1, BRCA2, and APC genes in Australian Ashkenazi Jews: implications for the generality of U.S. population data. Cancer 2001; 92: 440-445.

7. Dillenburg CV, Bandeira IC, Tubino TV i wsp. Prevalence of 185 delAG and 5382ins $C$ mutations in BRCA1, and 6174delT in BRCA2 in women of Ashkenazi Jewish origin in southern Brazil. Genet Mol Biol 2012; 35: 599-602.

8. Janavicius R. Founder BRCA1/2 mutations in the Europe: implications for hereditary breast-ovarian cancer prevention and control. EPMA J 2010; 1: 397-412.

9. Wang $F$, Fang $\mathrm{Q}$ Ge Z i wsp. Common BRCA1 and BRCA2 mutations in breast cancer families: a meta-analysis from systematic review. Mol Biol Rep 2012; 39: 2109-2118.

10. Gayther $S A$, Harrington $P$, Russell P i wsp. Frequently occurring germline mutations of the BRCA1 gene in ovarian cancer families from Russia. Am J Hum Genet 1997; 60: 1239-1242.

11. Sylyn A, Martynkov V, Rodko D i wsp. Evaluation of hereditary predisposition to breast cancer by testing the most common mutations in genes BRCA1 and BRCA2 in a group of patients from the Gomel region of Belarus. Health Issues and the Environment 2009; 4: 100-108.

12. Sokolenko AP, Rozanov ME, Mitiushkina NV i wsp. Founder mutations in early-onset, familial and bilateral breast cancer patients from Russia. Fam Cancer 2007; 6: 281-286.

13. Anisimenko MS, Mitrofanov DV, Chasovnikova OB i wsp. BRCA1 gene mutations frequency estimation by allele-specific real-time PCR of pooled genomic DNA samples. Breast 2013; 22: 532-536.
14. Górski B, Byrski T, Huzarski T i wsp. Founder mutations in the BRCA1 gene in Polish families with breast-ovarian cancer. Am J Hum Genet 2000; 66: 1963-1968.

15. Górski B. Selected aspects of molecular diagnostics of constitutional alterations in BRCA1 and BRCA2 genes associated with increased risk of breast cancer in the Polish population. Hered Cancer Clin Pract 2006; 4: 142-152.

16. Gronwald J, Huzarski T, Byrski Bi wsp. Cancer risks in first degree relatives of BRCA1 mutation carriers: effects of mutation and proband disease status. J Med Genet. 2006; 43: 424-428.

17. Górski B, Jakubowska A, Huzarski Ti wsp. A high proportion of founder BRCA1 mutations in Polish breast cancer families. Int J Cancer 2004; 110 : 683-686.

18. Blecharz P, SzatkowskiW, Klimek M i wsp. [The prevalence of BRCA1 mutations among families at high-risk of breast and ovarian cancer in province of Malopolska between 2004-2009]. Przegl Lek 2009; 66: 1046-1048.

19. Gaj P, Kluska A, Nowakowska D i wsp. High frequency of BRCA1 founder mutations in Polish women with nonfamilial breast cancer. Fam Cancer 2012; 11: 623-628.

20. Grzybowska E, Siemińska M, Zientek H i wsp. Germline mutations in the BRCA1 gene predisposing to breast and ovarian cancers in Upper Silesia population. Acta Biochim Pol 2002; 49: 351-356.

21. Janiszewska $\mathrm{H}$, Haus $\mathrm{O}$, Lauda-Swieciak $\mathrm{A}$ i wsp. Frequency of three BRCA1 gene founder mutations in breast/ovarian cancer families from the Pomerania-Kujawy region of Poland. Clin Genet 2003; 64: 502-508.

22. Laitman Y, Simeonov M, Herskovitz L i wsp. Recurrent germline mutations in BRCA1 and BRCA2 genes in high risk families in Israel. Breast Cancer Res Treat 2012; 133: 1153-1157.

23. Bogdanova NV, Antonenkova NN, Rogov YI i wsp. High frequency and allele-specific differences of BRCA 1 founder mutations in breast cancer and ovarian cancer patients from Belarus. Clin Genet 2010; 78: 364-372.

24. Tamboom K, Kaasik K, Arsavskaja J i wsp. BRCA1 mutations in women with familial or early-onset breast cancer and BRCA2 mutations in familial cancer in Estonia. Hered Cancer Clin Pract 2010; 8: 4.

25. Elsakov P, Kurtinaitis J, Petraitis S i wsp. The contribution of founder mutations in BRCA1 to breast and ovarian cancer in Lithuania. Clin Genet 2010; 78: 373-376.

26. Gronwald J, Elsakov P, Górski B, Lubiński J. High incidence of 4153 delA BRCA1 gene mutations in Lithuanian breast - and breast-ovarian cancer families. Breast Cancer Res Treat. 2005; 94: 111-113.

27. Tikhomirova L, Sinicka O, Smite Di wsp. High prevalence of two BRCA1 mutations, 4154delA and 5382insC, in Latvia. Fam Cancer 2005; 4: 77-84.

28. Gardovskis A, Irmejs A, Miklasevics E i wsp. Clinical, molecular and geographical features of hereditary breast/ovarian cancer in Latvia. Hered Cancer Clin Pract 2005; 3: 71-76.

29. Csokay B, Tihomirova L, Stengrevics A i wsp. Strong founder effects in BRCA1 mutation carrier breast cancer patients from Latvia. Mutation in brief no. 258. Online. Hum Mutat 1999; 14: 92.

30. Ozolina S, Sinicka O, Jankevics E i wsp. The 4154delA mutation carriers in the BRCA1 gene share a common ancestry. Fam Cancer 2009; 8: 1-4.

31. Nadtoka O. Baltic-Black Sea Union: historical retrospective and political perspective. Scientific Notes. Volume 22, Part 1, Humanities National University of "Kyiv-Mohyla Academy". Kyiv: Publishing house „KM Academy" 2003: 148-157.

32. Krylova NY, Lobeiko OS, Sokolenko AP i wsp. BRCA1 4153delA founder mutation in Russian ovarian cancer patients. Hered Cancer Clin Pract 2006; 4: 193-196.

33. Lawniczak M, Gawin A, Białek A i wsp. Is there any relationship between BRCA1 gene mutation and pancreatic cancer development? Pol Arch Med Wewn 2008; 118: 645-649.

34. Abele A, Vjaters E, Irmejs A i wsp. Epidemiologic, clinical, and molecular characteristics of hereditary prostate cancer in Latvia. Medicina (Kaunas) 2011; 47: 579-585.

35. Cybulski C, Górski B, Gronwald J i wsp. BRCA1 mutations and prostate cancer in Poland. Eur J Cancer Prev 2008; 17: 62-66.

36. Cybulski C, Wokołorczyk D, KluźniakW i wsp. An inherited NBN mutation is associated with poor prognosis prostate cancer. Br J Cancer 2013; 108: $461-468$. 